\title{
KETEPATAN PEMBERIAN OPINI AUDITOR : SURVEY TERHADAP AUDITOR DI YOGYAKARTA
}

\author{
Abriyani Puspaningsih ${ }^{*}$, Noeroel Fadlilah ${ }^{2}$ \\ 1,2 Program Studi Akuntansi, Fakultas Ekonomi, Universitas Islam Indonesia \\ *Korespondensi: abriyani@uii.ac.id
}

\begin{abstract}
This study aims to examine the accuracy of giving opinion by the auditor. Factors that are expected to have an effect on the accuracy of the auditor's opinion are professional skepticism, experience, audit situation, expertise and workload. This research was conducted by survey method using questionnaires distributed to auditors working in the public accounting firm in Yogyakarta. The sampling technique using a random sampling.

The results showed that the variables of professional skepticism and audit situation has significant positive effect on the accuracy of giving opinions by the auditor. There are three variables that do not have a significant effect on the accuracy of giving the auditor's opinion in this study, namely the experience, expertise, and workload. This is because the auditors who were respondents in this study are mostly junior auditor, with an educational background $\mathrm{SI}$ is still a bit of experience, expertise and workload.
\end{abstract}

\begin{abstract}
ABSTRAK
Penelitian ini bertujuan untuk menguji ketepatan pemberian opini oleh auditor. Faktor yang diperkirakan memiliki pengaruh terhadap ketepatan pemberian opini auditor adalah skeptisisme profesional, pengalaman, situasi audit, keahlian dan beban kerja. Penelitian ini dilakukan dengan metode survei menggunakan kuesioner yang dibagikan kepada auditor yang bekerja pada Kantor Akuntan Publik di Daerah Istimewa Yogyakarta. Teknik pengambilan sampel menggunakan simple random sampling. Hasil penelitian menunjukkan bahwa variabel skeptisisme profesional dan situasi audit berpengaruh positif signifikan terhadap ketepatan pemberian opini oleh auditor. Terdapat tiga variabel yang tidak berpengaruh signifikan terhadap ketepatan pemberian opini auditor dalam penelitian ini, yaitu pengalaman, keahlian, dan beban kerja. Hal ini disebabkan karena auditor yang menjadi responden dalam penelitian ini sebagian besar adalah auditor junior, dengan latar belakang pendidikan S1 yang masih sedikit pengalaman, keahlian maupun beban kerjanya.
\end{abstract}

Keywords: audit situations, audit opinion, expertise, experience, skepticism, workload

\section{PENDAHULUAN}

Audit adalah proses pemeriksaan yang dilakukan secara kritis dan sistematis oleh pihak yang independen, terhadap laporan keuangan yang telah disusun oleh manajemen beserta catatancatatan pembukuan dan bukti-bukti pendukungnya dengan tujuan untuk dapat memberikan pendapat mengenai kewajaran laporan keuangan tersebut (Agoes, 2012). Tujuan akhir dari proses audit adalah menghasilkan suatu laporan audit, yang didalamnya berisi pendapat atau opini mengenai kewajaran laporan keuangan. Laporan keuangan yang telah diaudit dan diberikan opini oleh akuntan publik dapat digunakan para pemakai laporan keuangan tersebut sebagai acuan dan bahan pertimbangan dalam pengambilan keputusan.

Auditor sebagai pihak yang bertanggung jawab terhadap pelaksanaan audit dan opini yang diberikan, oleh karena itu audit harus dilaksanakan dengan sebaik-baiknya. Maraknya kasus- 
kasus manipulasi keuangan yang melibatkan kantor-kantor akuntan publik yang terjadi di beberapa negara termasuk di Indonesia telah membuat kepercayaan masyarakat khususnya para pemakai laporan keuangan auditan mulai menurun. Misalnya kasus Enron yang melibatkan KAP Arthur Andersen di Amerika Serikat. Kasus ini berakibat pada menurunnya kepercayaan investor terhadap integritas penyajian laporan keuangan. Di Indonesia, juga terdapat kasus serupa, diantaranya adalah laporan keuangan ganda Bank Lippo untuk periode 30 September tahun 2002. Kasus yang lain adalah adanya mark up atas laporan keuangan tahun 2001 oleh manajemen PT. Kimia Farma Tbk. Perusahaan ini melaporkan overstated laba bersih sebesar Rp. 132 miliar (Winantyadi dan Waluyo, 2014).

Keterlibatan dan kesalahan auditor dalam kasus-kasus di atas adalah karena auditor terlambat menyadari dan melaporkan ketidakberesan yang telah dilakukan oleh pihak manajemen perusahaan. Kegagalan auditor dalam mendeteksi kecurangan yang dilakukan manajemen perusahaan terjadi karena rendahnya tingkat skeptisisme profesional yang dimiliki oleh auditor.

Penting bagi auditor untuk memiliki sikap skeptis yang tinggi agar dapat menentukan sejauh mana tingkat keakuratan dan kebenaran bukti-bukti maupun informasi yang diperoleh dari klien, agar tidak tercipta suatu kegagalan dalam proses audit. Standar profesional akuntan publik mendefinisikan skeptisisme profesional sebagai sikap auditor yang mencakup pikiran yang selalu mempertanyakan dan melakukan evaluasi secara kritis terhadap bukti audit (SPAP, 2011). Standar audit tersebut mensyaratkan agar auditor memiliki sikap skeptisisme profesional dalam mengevaluasi, mengumpulkan dan menganalisa bukti audit agar dapat memberikan opini secara tepat. Penerapan skeptisisme profesional yang memadai, akan membantu auditor mendeteksi potensi salah saji material dalam laporan keuangan sehingga dapat meminimalisir risiko pengguna laporan keuangan memperoleh informasi yang menyesatkan dan mengambil keputusan yang salah.

Pengalaman dan keahlian juga merupakan faktor penting yang harus dimiliki auditor. Pengalaman ditunjukkan dengan jam terbang auditor dalam melakukan tugasnya. Pengalaman ini dapat mempengaruhi auditor dalam memberikan opini. Semakin banyak pengalaman yang dimiliki auditor, maka auditor akan lebih dapat mendeteksi kecurangan-kecurangan yang ada pada laporan keuangan. Dengan demikian semakin tinggi kmampuan menentukan pendapat mana yang paling sesuai yang akan diberikan atas laporan keuangan yang diperiksa dengan tepat. Christiawan (2002) juga menjelaskan bahwa semakin banyak dan kompleks tugas-tugas yang dilakukan seorang individu akan menyebabkan pengalaman individu tersebut semakin meningkat karena hal ini akan menambah dan memperluas wawasan yang dimiliki. Tirta dan Sholihin (2004) dalam penelitiannya menyimpulkan bahwa Semakin banyak pengalaman auditor, semakin tinggi pula tingkat keakuratan auditor dalam memberikan opini.

Faktor lain yang diduga mempengaruhi ketepatan pemberian opini adalah situasi audit. Dalam melaksanakan tugasnya, auditor terkadang dihadapkan pada berbagai macam situasi. 
Situasi yang memiliki resiko tinggi antara lain adanya hubungan istimewa, kualitas komunikasi, klien yang tidak kooperatif, klien baru pertama kali diaudit dan klien bermasalah (Suraida, 2005). Situasi ini menuntut auditor untuk memiliki tingkat kewaspadaan yang tinggi terhadap penyajian yang salah terutama salah saji material dan kecurangan yang mungkin terjadi agar audit yang dilakukan efektif. Dengan situasi yang memiliki resiko tinggi yang mengakibatkan ada ketidakpastian mengenai kompetensi bukti yang diperoleh auditor, maka auditor akan lebih berhati-hati dalam memperoleh bukti kompeten dan menganilisis temuan-temuannya, sehingga dapat memberikan opini yang tepat.

Standar umum yang pertama SA Seksi 210, SPAP (2011) bahwa audit harus dilaksanakan oleh seorang atau lebih yang memiliki keahlian dan pelatihan teknis yang cukup sebagai auditor. Dimana seorang ahli adalah seorang yang memiliki tingkat ketrampilan yang tinggi, yang dengan ketrampilannya mengerjakan pekerjaan dengan mudah, cepat, intuitif dan sangat jarang bahkan tidak pernah membuat kesalahan.

Beban kerja yang terlalu berat dapat mempengaruhi seorang auditor dalam melaksanakan pekerjaan audit. Lopez dan Peters (2011) menyatakan bahwa ketika berada pada masa - masa sibuk (biasanya pada awal tahun) auditor mengalami kelelahan, sehingga mengakibatkan menurunnya kemampuan auditor untuk mendeteksi kecurangan. Hal yang sama disimpulkan dari penelitian Fitriany (2011), yang menyatakan bahwa beban kerja memiliki dampak negatif terhadap kualitas audit. Penelitian tersebut mendukung bahwa beban kerja adalah salah satu faktor yang menyebabkan auditor gagal memberikan opini yang tepat dalam laporan audit.

Penelitian mengenai ketepatan pemberian opini auditor beberapa diantaranya pernah dilakukan oleh Suraida (2005), Gusti dan Ali (2008), Kushasyandita dan Januarti (2012) serta Surfeliya (2014). Dari masing-masing penelitian diperoleh hasil yang berbeda-beda dan tidak konsisten sehingga perlu dilakukan penelitian lebih lanjut untuk mengetahui ada tidaknya pengaruh dari masing-masing variabel yang telah digunakan dalam penelitian sebelumnya dan peneliti akan meneliti mengenai beban kerja yang diduga berpengaruh negatif terhadap ketepatan pemberian opini. Melihat pentingnya ketepatan pemberian opini audit oleh auditor maka peneliti hendak melakukan penelitian mengenai hal tersebut di atas dengan mengkombinasikan penelitian yang dilakukan oleh Surfeliya, Kushasyandita (2012) dan penelitian Gusti dan Ali (2008). Kemudian peneliti menambahkan variabel beban kerja yang diadopsi dari penelitian Nasution (2012). Beban kerja yang tinggi akan menyebabkan seorang auditor kelelahan dalam melaksanakan tugas sehingga kemampuannya dalam mendeteksi kecurangan menjadi berkurang. Apabila auditor tidak mampu mendeteksi kecurangan dalam auditnya maka ada kemungkinan opini yang diberikan tidak tepat atau tidak sesuai dengan kondisi yang sesungguhnya dari perusahaan yang diaudit. 
Berdasarkan penjelasan di atas, maka tujuan penelitian ini adalah : untuk menguji dan memberikan bukti empiris mengenai pengaruh skeptisisme, pengalaman, situasi, keahlian dan beban kerja terhadap ketepatan pemberian opini auditor. Adapun manfaat dari penelitian ini bagi akademisi dapat bermanfaat untuk mengembangkan ilmu perilaku terutama audit, bagi auditor dapat dijadikan acuan untuk meningkatkan sikap skeptis, pengalaman dan keahliannya dalam melakukan audit supaya audit yang dilakukannya berkualitas, bagi masyarakat dapat membantu untuk meningkatkan kepercayaan masyarakat kepada akuntan publik.

\section{TINJAUAN PUSTAKA}

\subsection{Opini Auditor Independen}

Opini auditor merupakan pendapat yang diberikan oleh auditor mengenai kewajaran penyajian laporan keuangan perusahaan tempat auditor melakukan audit. Opini audit merupakan bagian yang tak terpisahkan dari laporan audit, dimana opini audit ini biasa disampaikan dalam paragraf pendapat. Terdapat 2 bentuk opini yang bisa diberikan oleh auditor dalam audit laporan keuangan yaitu : (1) Opini tanpa modifikasian (Unmodified opinion); dan (2) Opini modifikasian (Modified opinion). Kemudian opini modifikasian dibagi menjadi 3 jenis yaitu : (1) Opini wajar dengan pengecualian; (2) Opini tidak wajar; (3) Opini tidak menyatakan pendapat. Diantara 4 opini tersebut, opini yang paling baik adalah Opini Tanpa Modifikasian (Unmodified Opinion). Opini ini diberikan karena auditor meyakini, berdasar bukti-bukti audit yang dikumpulkan, laporan keuangan telah bebas dari kesalahan-kesalahan atau kekeliruan yang material dan telah memberikan gambaran yang benar dan wajar sesuai dengan kerangka pelaporan yang berlaku. Opini terbaik kedua adalah Opini Wajar Dengan Pengecualian. Auditor harus menyatakan opini wajar dengan pengecualian ketika auditor setelah memperoleh bukti audit yang cukup dan tepat, menyimpulkan bahwa kesalahan penyajian, baik secara individual maupun secara agregasi adalah material, tetapi tidak pervasif, terhadap laporan keuangan atau auditor tidak dapat memperoleh bukti audit yang cukup dan tepat yang mendasari opini tetapi auditor menyimpulkan bahwa pengaruh kesalahan penyajian yang tidak terdeteksi yang mungkin timbul terhadap laporan keuangan, jika ada, dapat menjadi material tetapi tidak pervasif. Opini paling buruk adalah Tidak Wajar. Opini diberikan karena auditor, setelah memperoleh bukti audit yang cukup dan tepat, menyimpulkan bahwa kesalahan penyajian, baik secara individual maupun secara agregasi, adalah material dan pervasif terhadap laporan keuangan. Artinya, laporan keuangan tidak menggambarkan kondisi keuangan secara benar. Opini Tidak Memberikan Pendapat atau Menolak Memberikan Pendapat tidak bisa diartikan bahwa laporan keuangan sudah benar atau salah. Opini tersebut diberikan karena auditor tidak dapat memperoleh bukti audit yang cukup dan tepat yang mendasari opini, dan auditor menyimpulkan bahwa pengaruh kesalahan penyajian yang tidak terdeteksi yang mungkin timbul terhadap laporan keuangan, jika ada, dapat bersifat 
material dan pervasif. Auditor harus tidak menyatakan pendapat ketika dalam kondisi yang sangat jarang melibatkan banyak ketidakpastian, auditor menyimpulkan bahwa, meskipun telah memperoleh bukti audit yang cukup dan tepat tentang setiap ketidakpastian tersebut, adalah tidak mungkin untuk merumuskan suatu opini atas laporan keuangan karena interaksi yang potensial dari ketidakpastian tersebut dan pengaruh kumulatif ketidakpastian tersebut yang mungkin timbul terhadap laporan keuangan (ISA $700 \& 705$, IAPI 2011).

\subsection{Skeptisisme Profesional Auditor}

Standar Profesi Akuntan Publik/SPAP (2011) menyatakan bahwa skeptisisme profesional auditor sebagai suatu sikap yang mencakup pikiran yang selalu mempertanyakan dan melakukan evaluasi secara kritis terhadap bukti audit. Skeptisisme, berasal dari kata skeptis dalam Kamus Besar Bahasa Indonesia yang berarti sikap meragukan, mencurigai dan tidak mempercayai kebenaran suatu hal, teori, ataupun pernyataan. Sedangkan profesional adalah sesuatu yang bersangkutan dengan profesi, yang membutuhkan keahlian khusus untuk menerapkannya. Auditor dituntut oleh profesi akuntan publik untuk melaksanakan dengan cermat dan seksama dalam pengumpulan dan penilaian bukti audit secara objektif. Pengumpulan dan penilaian bukti audit secara objektif ini menuntut auditor mempertimbangkan kompetensi dan kecukupan bukti audit tersebut. Oleh karena itu bukti audit harus dikumpulkan dan dinilai selama proses audit, sehingga dibutuhkan skeptisisme profesional selama proses tersebut agar nantinya perumusan opininya tepat. Bukti audit akan digunakan sebagai dasar dalam perumusan opini auditor. Hal ini sejalan dengan hasil penelitian Surfeliya (2014) menyimpulkan bahwa skeptisisme berpengaruh signifikan terhadap ketepatan pemberian opini audit. Hal yang sama juga disimpulkan dari penelitian Gusti dan Ali (2008).

\subsection{Pengalaman}

Pengalaman merupakan suatu proses yang membawa seseorang kepada suatu pola tingkah laku yang lebih tinggi. Pengalaman mampu memberikan peluang yang besar bagi seseorang untuk melakukan pekerjaan yang lebih baik. Pengalaman yang dimaksud disini adalah pengalaman auditor dalam melakukan pemeriksaan laporan keuangan baik dari segi lamanya waktu, banyaknya penugasan, maupun jenis-jenis perusahaan yang pernah ditangani (Asih, 2006). Libby and Frederick (1990) menemukan bahwa semakin banyak pengalaman auditor semakin dapat menghasilkan berbagai macam dugaan dalam menjelaskan temuan audit. Butt (1998) juga mengungkapan bahwa akuntan pemeriksa yang berpengalaman akan membuat judgment yang relatif lebih baik dalam tugas-tugas profesional ketimbang akuntan pemeriksa yang belum berpengalaman. Akuntan pemeriksa yang berpengalaman mampu mengidentifikasi secara lebih baik mengenai kesalahan-kesalahan dalam telaah analitik. Auditor yang telah memiliki banyak pengalaman tidak hanya memiliki kemampuan untuk menentukan dan menemukan bentuk kekeliruan atau kecurangan yang tidak lazim yang ada dalam laporan keuangan, tetapi juga auditor tersebut dapat memberikan penjelasan yang lebih akurat terhadap temuannya tersebut, 
dibandingkan dengan auditor yang masih sedikit pengalaman (Libby dan Frederick, 1990). Jadi auditor yang lebih berpengalaman akan lebih tinggi tingkat ketepatan dalam pemberian opininya dibandingkan dengan auditor yang kurang berpengalaman atau sedikit pengalamannya. Penelitian Sukendra (2015) memberikan bukti bahwa pengalaman auditor berpengaruh positif signifikan terhadap ketepatan pemberian opini auditor.

\subsection{Situasi Audit}

Situasi audit diartikan sebagai suatu keadaan, suasana dan kondisi yang terjadi pada saat audit dilaksanakan. Menurut Arens (2007) situasi seperti kesulitan untuk berkomunikasi dengan auditor lama terkait informasi perusahaan; situasi ketika klien yang diaudit merupakan klien yang baru pertama kali diaudit; situasi kemungkinan adanya motivasi manajemen untuk menarik investor, diduga akan mempengaruhi auditor dalam memberikan opini. Faktor situasi audit akan menentukan sikap auditor dan perilaku, yang nantinya akan dilakukan oleh auditor dalam mengolah informasi sampai menghasilkan opini. Penelitian Gusti dan Ali (2008) telah membuktikan bahwa situasi audit berpengaruh signifikan terhadap ketepatan pemberian opini audit.

\subsection{Keahlian}

Keahlian merupakan kemampuan mendasar seorang auditor berupa pengetahuan dan kemampuan dalam lingkup akuntansi dan auditing secara umum. Keahlian auditor ini merupakan hasil dari pendidikan formal, ujian profesional maupun keikutsertaan dalam penelitian, seminar, simposium dan lain-lain. Seorang auditor, haruslah memiliki keahlian dalam melaksanakan audit. Pernyataan tersebut sesuai dengan standar umum pertama dari Standar Auditing Seksi 210, SPAP (2011) yang menyatakan bahwa audit harus dilaksanakan oleh seorang atau entitas yang memiliki keahlian dan pelatihan khusus yang cukup sebagai auditor. Pada saat penugasan audit, cara yang dilakukan auditor junior dengan auditor senior tentu akan berbeda dalam melakukan pertimbangan guna memberikan pendapat. Oleh karena itu keahlian akan mempengaruhi ketepatan seorang auditor dalam memberikan opini. Penelitian Sukendra (2015) memberikan bukti bahwa keahlian auditor berpengaruh positif signifikan terhadap ketepatan pemberian opini auditor.

\subsection{Beban Kerja}

Beban kerja adalah lama seseorang melakukan aktivitas pekerjaan sesuai dengan kemampuan dan kapasitas kerja yang bersangkutan tanpa menunjukkan kelelahan. Fitriany (2011) menyebutkan bahwa beban kerja auditor dapat dilihat dari seberapa banyak klien yang ditangani oleh auditor tersebut dan terbatasnya waktu seorang auditor untuk melakukan proses auditnya. Beban kerja audit biasanya berkaitan dengan busy season yang terjadi karena banyaknya perusahaan yang memiliki tahun fiskal yang berakhir di bulan Desember. Kelebihan pekerjaan pada saat busy season akan mengakibatkan kelelahan dan ketatnya time budget auditor sehingga akan menghasilkan kualitas audit yang rendah (Lopez dan Peters, 2011). 
Dhania (2010) penyebab tingkat stress seseorang bisa dipengaruhi oleh faktor internal atau eksternal dimana faktor eksternal itu adalah beban kerja. Jelas dengan mempengaruhinya beban kerja terhadap tingkat stress maka akan mempengaruhi kinerja seseorang. Begitu juga dengan auditor, semakin tinggi beban kerja yang ditanggungnya semakin tinggi pula tingkat stress yang terjadi dan akan mengakibatkan semakin rendah juga kualitas auditnya yang dapat berakibat pada ketidaktepatan dalam pemberian opini oleh auditor. Hasil penelitian Nasution (2012) memberikan bukti bahwa beban kerja berpengaruh negatif terhadap ketepatan pemberian opini audit.

\subsection{Pengembangan Hipotesis}

\subsubsection{Pengaruh Skeptisisme profesional terhadap ketepatan pemberian opini auditor}

Skeptisisme profesional auditor adalah sikap skeptis yang dimiliki auditor yang selalu mempertanyakan dan meragukan bukti audit. Dapat diartikan bahwa skeptisisme profesional menjadi salah satu faktor dalam menentukan kemahiran profesional seorang auditor. Kemahiran profesional akan sangat mempengaruhi ketepatan pemberian opini. Dengan demikian semakin tinggi tingkat skeptisisime seorang auditor dalam melakukan audit, maka diduga akan berpengaruh pada ketepatan pemberian opini auditor tersebut. Dalam penelitian Sukendra dan Yuniarta (2015) membuktikan bahwa skeptisisme berpengaruh positif signifikan terhadap ketepatan pemberian opini auditor. Bahkan dalam pengujiannya, variabel skeptisisme profesional memiliki pengaruh yang paling dominan terhadap ketepatan pemberian opini auditor. Penelitian lain milik Gusti dan Ali (2008) mengenai Hubungan Skeptisime Profesional dengan Ketepatan Pemberian Opini Auditor oleh Akuntan Publik juga menemukan bahwa terdapat hubungan yang signifikan antara skeptisime profesional dengan ketepatan pemberian opini auditor. Berdasarkan penjelasan diatas, maka hipotesis yang dapat dirumuskan :

H1 : Skeptisisme profesional berpengaruh positif terhadap ketepatan pemberian opini auditor.

\subsubsection{Pengaruh Pengalaman terhadap Ketepatan Pemberian Opini Auditor}

Pengalaman auditor dapat ditinjau dari segi lamanya waktu maupun banyaknya penugasan yang pernah ditangani (Suraida, 2005). Semakin banyak dan kompleks tugas-tugas yang dilakukan seorang auditor, semakin auditor tersebut berpengalaman dan semakin luas wawasan yang dimiliki (Suraida, 2005). Auditor yang berpengalaman tentu akan memiliki kemampuan untuk menemukan kekeliruan atau kecurangan yang tidak lazim dalam laporan keuangan dan juga dapat memberikan penjelasan yang lebih akurat terhadap temuannya tersebut dibandingkan dengan auditor yang masih sedikit pengalamannya. Putu Sukendra (2015) dalam penelitiannya menemukan bahwa pengalaman auditor berpengaruh signifikan positif terhadap ketepatan pemberian opini oleh auditor, serta penelitian Suraida (2005) yang menunjukkan 
pengalaman audit secara parsial maupun simultan berepngaruh positif terhadap ketepatan pemberian opini akuntan. Berdasarkan penjelasan diatas, maka hipotesis yang dapat dirumuskan

$\mathrm{H} 2$ : Pengalaman berpengaruh positif terhadap ketepatan pemberian opini auditor

\subsubsection{Pengaruh Situasi Audit Terhadap Ketepatan Pemberian Opini Auditor}

Apabila dalam penugasannya auditor menemukan situasi irregulates atau situasi yang mengandung risiko tinggi, maka diperlukan bukti yang lebih banyak dan informasi yang relevan guna memberikan keyakinan yang memadai atas pendeteksian salah saji material dalam laporan keuangan (Gusti dan Ali, 2008). Situasi yang mengandung resiko besar mempengaruhi auditor dalam memperoleh bukti yang cukup dan memadai. Dengan adanya resiko yang besar, menuntut auditor untuk meningkatkan kewaspadaan terhadap kecurangan yang mungkin terjadi agar audit yang dilakukaannya efektif. Irregularities sering diartikan sebagai suatu situasi di mana terdapat ketidakberesan atau kecurangan yang dilakukan dengan sengaja (Zein, 2011). Penelitian Gusti dan Ali (2008) membuktikan bahwa situasi audit memiliki hubungan yang positif signifikan dengan ketepatan pemberian opini auditor oleh akuntan publik. Berdasarkan penjelasan diatas, maka hipotesis yang dapat dirumuskan:

H3 : Situasi Audit berpengaruh positif terhadap ketepatan pemberian opini auditor.

\subsubsection{Pengaruh Keahlian Terhadap Ketepatan Pemberian Opini Auditor}

Auditor harus memiliki keahlian yang diperlukan dalam tugasnya, keahlian ini meliputi keahlian mengenai audit yang mencakup antara lain: merencanakan program kerja pemeriksaan, menyusun program kerja pemeriksaan, melaksanakan program kerja pemeriksaan, menyusun kertas kerja pemeriksaan, menyusun berita pemeriksaan, dan laporan hasil pemeriksaan. Penelitian Sukendra, Yuniarta dan Atmadja (2015) membuktikan bahwa keahlian berpengaruh positif signifikan terhadap ketepatan pemberian opini auditor. Berdasarkan penjelasan diatas, maka hipotesis yang dapat dirumuskan :

H4 : Keahlian audit berpengaruh positif terhadap ketepatan pemberian opini auditor.

\subsubsection{Pengaruh Beban Kerja terhadap Ketepatan Pemberian Opini Auditor}

Fitriany (2011) menemukan bahwa beban kerja auditor berpengaruh negatif terhadap kualitas audit. Beban kerja yang semakin meningkat akan menurunkan kemampuan auditor dalam mendeteksi kekeliruan atau kecurangan sebuah perusahaan yang akan berakibat juga dengan kualitas audit yang dihasilkan menjadi rendah (Fitriany, 2011). Berdasarkan konsep tersebut maka penulis menduga bahwa semakin banyak beban kerja yang dimiliki oleh auditor akan meningkatkan kekeliruan auditor dalam memberikan opini.

Dalam penelitian yang dilakukan Nasution (2012) membuktikan bahwa hasil pengujian menunjukkan beban kerja berpengaruh negatif terhadap peningkatan kemampuan auditor dalam mendeteksi gejala-gejala kecurangan. Artinya beban kerja auditor yang banyak atau menumpuk dapat mengurangi sikap skeptisisme profesional yang akan berdampak pada ketidaktepatan 
pemberian opini auditor. Begitu juga dengan pendapat Murtiasri dan Ghozali (2006) menemukan bahwa beratnya beban pekerjaan akan menurunkan kepuasan kerja dan kinerja auditor yang artinya akan mempengaruhi pada ketidaktepatan pemberian opini auditor. Hal ini menjadi dasar yang kuat untuk merumuskan hipotesis pengaruh beban kerja terhadap ketepatan pemberian opini auditor. Berdasarkan penjelasan diatas, maka hipotesis yang dapat dirumuskan:

H5 : Beban kerja berpengaruh negatif terhadap ketepatan pemberian opini auditor

Berdasarkan kajian di atas, maka model penelitian dapat digambarkan seperti dalam Gambar 1. berikut ini :

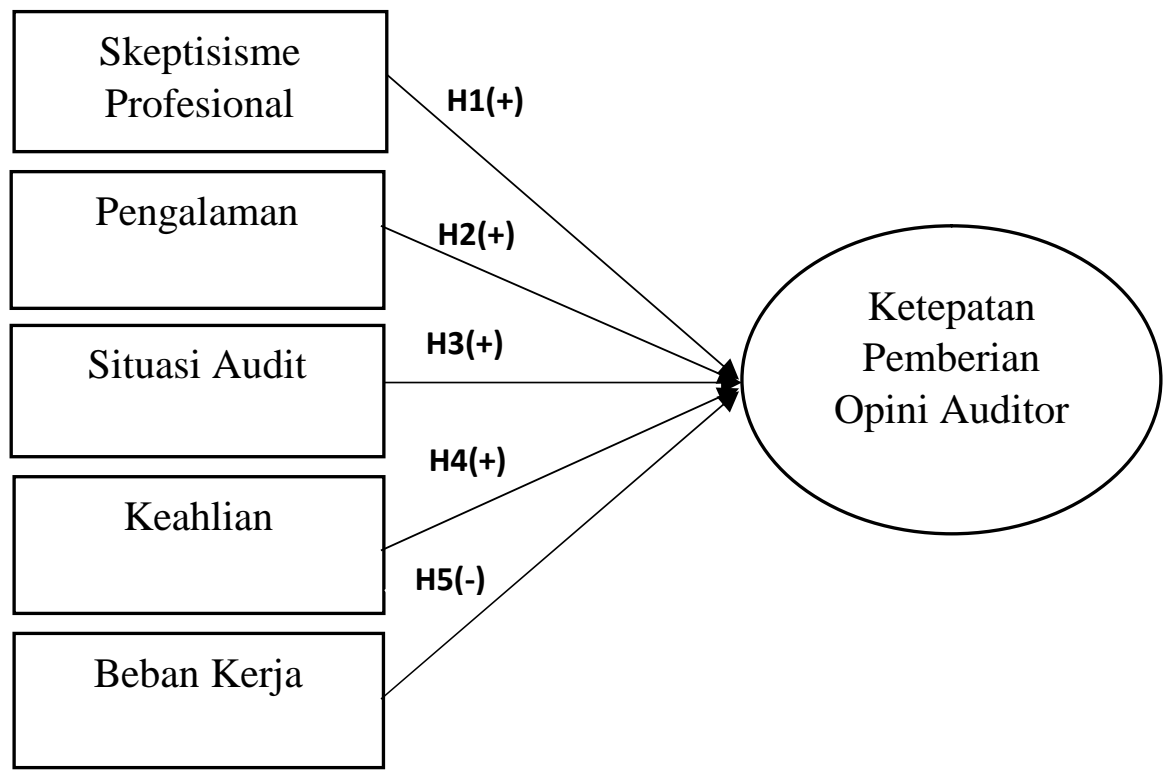

Gambar 1. Model Penelitian

\section{METODE}

\subsection{Populasi dan Sampel}

Populasi dalam penelitian ini adalah seluruh KAP yang terdapat di Daerah Istimewa Yogyakarta. Sedangkan sampel dalam penelitian ini adalah seluruh auditor baik dari tingkatan partner, manajer, junior auditor maupun senior auditor yang terdapat pada masing-masing KAP di Yogyakarta. Pengambilan sampel dilakukan random sampling yaitu teknik pengambilan anggota sampel dari populasi, yang dilakukan secara acak tanpa memperhatikan strata yang ada di dalam populasi. Metode ini dipilih agar semua auditor pada tiap KAP yang ada di Yogyakarta memiliki kesempatan atau peluang yang sama untuk terpilih sebagai sampel.

\subsection{Teknik Pengumpulan Data}

Teknik pengumpulan data menggunakan metode survei melalui kuesioner, yaitu dengan cara menyebarkan kuesioner kepada auditor yang bekerja pada KAP di Yogyakarta. Kuesioner 
berisi ilustrasi kasus dan daftar pertanyaan, kemudian auditor diminta untuk memberikan pendapatnya terhadap kasus dengan cara menjawab pertanyaan yang diajukan.

\subsection{Definisi Operasional dan Pengukuran Variabel Penelitian}

Penelitian ini menggunakan satu variabel dependen dan lima variabel independen. Berikut adalah penjelasan masing-masing variabel yang digunakan dalam penelitian ini.

\subsection{Ketepatan Pemberian Opini Auditor}

Hasil akhir dari proses audit yaitu laporan audit yang di dalamnya berisi opini auditor. Pemberian opini oleh auditor harus tepat dan akurat karena hal ini berkaitan juga dengan kepercayaan publik akan profesi akuntan. Opini yang disajikan dalam laporan audit dijadikan dasar oleh mereka yang berkepentingan atas laporan keuangan tersebut, untuk dasar pengambilan keputusan. Variabel ketepatan pemberian opini auditor diukur melalui pemberian opini yang sesuai dengan kriteria-kriteria yang ditetapkan dalam macam-macam opini. Responden diminta untuk mengisi opini apa yang diberikan pada setiap ilustrasi di kuesioner. Kuesioner pada penelitian ini menggunakan serangkaian ilustrasi yang dipakai oleh Kushasyandita (2012) dengan skala likert kemudian jawaban responden akan dinilai dari kunci jawaban yang benar, sehingga dapat terlihat opini yang diberikan responden atas ilustrasi-ilustrasi tersebut tepat atau tidak tepat. Oleh karena itu skala yang digunakan adalah 1 tepat dan 0 tidak tepat.

\subsection{Skeptisisme Profesional}

Skeptisisme profesional adalah sikap keraguan, penuh pertanyaan dan penilaian kritis atas setiap bukti audit yang diperoleh. Indikator yang digunakan adalah (1) tingkat keraguan auditor terhadap bukti audit, (2) banyaknya pemeriksaan tambahan, (3) konfirmasi langsung (Kushasyandita, 2012). Pengukurannya, melalui kuesioner yang diberikan pada responden melalui serangkaian situasi dan skenario menggunakan skala likert lima point.

\subsection{Pengalaman}

Pengalaman audit adalah pengalaman dalam melakukan audit laporan keuangan baik dari segi lamanya waktu, banyaknya penugasan maupun jenis-jenis perusahaan yang pernah ditangani. Indikator yang digunakan adalah lamanya bekerja di KAP dan banyaknya tugas pemeriksaan. Instrumen penelitian yang digunakan adalah instrumen penelitian Adrian (2013) dengan menggunakan pengukuran skala likert lima point.

\subsection{Situasi Audit}

Situasi audit adalah suatu keadaan saat penugasan audit, dimana auditor dihadapkan pada situasi yang mengandung resiko rendah atau keadaan resiko tinggi. Instrumen penelitian yang digunakan untuk situasi audit menggunakan lima ilustrasi milik Kushasyandita (2012), kemudian auditor diminta utnutk memberikan tanggapan atas intensi perilaku bila auditor berada pada lima situasi tersebut. Ilustrasi pertama mengenai related party transaction, ilustrasi kedua mengenai motive klien untuk melakukan misstate, ilustrasi ketiga mengenai kualitas komunikasi antara klien dengan auditor, ilustrasi keempat mengenai klien yang baru pertama kali diaudit dan 
ilustrasi kelima mengenai indikasi klien bermasalah. Skala pengukuran yang digunakan adalah skala likert lima point.

\subsection{Keahlian}

Indikator pengukuran keahlian pada penelitian ini adalah tingkat pendidikan, kemampuan dan tingkat sertifikasi yang dimiliki oleh auditor atas pertanyaan pada kuesioner mengenai keahlian audit. Semakin tinggi keahliannya maka semakin tepat pemberian opini atas laporan keuangan (Suraida, 2005). Pertanyaan mengenai variabel keahlian ini berbentuk pertanyaan dengan menggunakan ilustrasi yang digunakan Kushasyandita dan Januarti (2012). Ilustrasi tersebut berisi pertanyaan pada responden untuk mengetahui kemampuan dan pengetahuan yang dimiliki auditor selama ia bekerja pada Kantor Akuntan Publik. Responden diminta untuk mengisi sesuai dengan pilihannya untuk memilih dari lima point skala likert yang tersedia pada kuesioner.

\subsection{Beban Kerja}

Beban kerja didefinisikan sebagai jumlah jam kerja yang dilaporkan oleh karyawan dan orang yang dilayani Shirom et. al, (2006). Ketatnya time budgets dapat menurunkan kemampuan auditor untuk menemukan kesalahan sehingga bisa dikatakan kurang skeptis dalam menentukan bukti yang cukup dan memadai serta akan berdampak pada ketidaktepatan pada pemberian opini. Instrumen penelitian yang digunakan adalah instrumen penelitian milik Pitaloka (2010) yang digunakan dalam penelitian Hergiawan (2013). Skala pengukuran yang digunakan untuk setiap nilai pertanyaan atau pernyataan yang diajukan dalam variabel beban kerja ini menggunakan skala likert lima point.

\subsection{Metode Analisis Kerja}

Metode analisis yang digunakan dalam penelitian adalah analisis regresi linear berganda untuk melihat pengaruh variabel independen terhadap variabel dependen, dengan model persamaan yang digunakan adalah sebagai berikut :

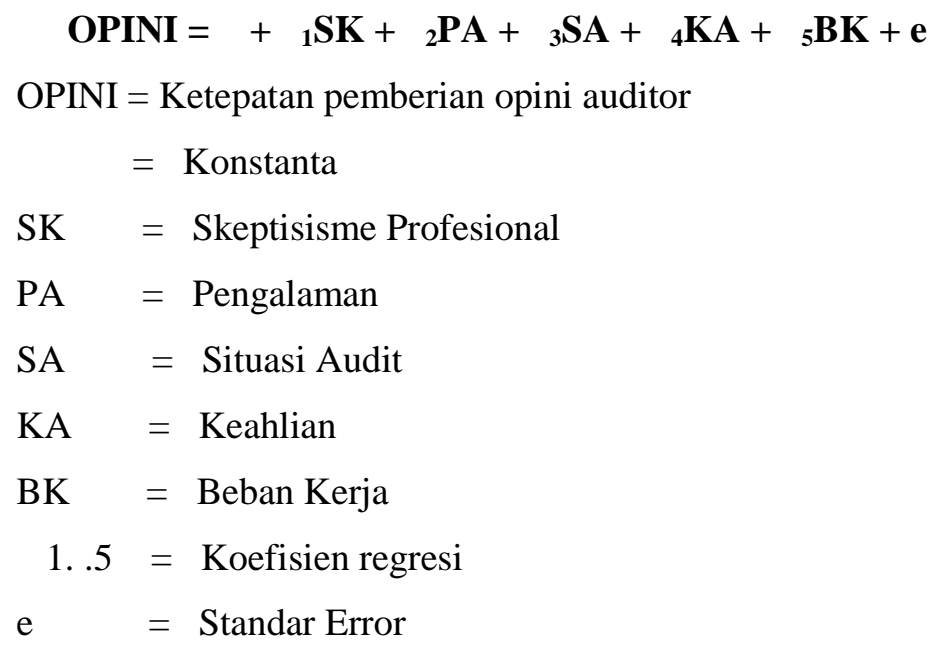




\section{HASIL DAN PEMBAHASAN}

\subsection{Pengumpulan Data}

Jumlah kuesioner yang disebar dalam penelitian ini adalah 48 eksemplar, dan dari 48 kuesioner yang disebar tersebut, yang dapat diolah sebanyak 37 kuesioner yang kemudian diuji dan dianalisis lebih lanjut. Tingkat pengembalian kuesioner dalam penelitian ini adalah $77,1 \%$. Menurut Ghozali (2005) syarat untuk bisa dilakukan pengolahan data yaitu dengan menggunakan sampel penelitian minimal 30 sampel. Jawaban kuesioner diperoleh dari 7 KAP yang ada di Daerah Istimewa Yogyakarta yaitu : 1) KAP Kumalahadi, Kuncara, Sugeng Pamudji \& Rekan. 2) KAP Indarto Waluyo. 3). KAP Bismar, Munthalib dan Yunus. 4). KAP Henry Susanto. 5). KAP Soeroso Donosapoetro. 6). KAP Moh. Mahsun. 7). KAP Hadiono.

\subsection{Deskripsi Responden}

Berikut karakteristik responden dalam penelitian ini pada Tabel 1. di bawah ini :

Tabel 1. Deskripsi Responden

\begin{tabular}{|c|c|c|}
\hline Jenis Kelamin & JUMLAH & $\%$ \\
\hline Perempuan & 25 & $32,4 \%$ \\
\hline Laki-laki & 12 & $67,6 \%$ \\
\hline Total & 37 & 100 \\
\hline \multicolumn{3}{|l|}{ Pendidikan } \\
\hline Diploma & 3 & $8,1 \%$ \\
\hline S1 & 29 & $78,4 \%$ \\
\hline $\mathrm{S} 2$ & 5 & $13,5 \%$ \\
\hline S3 & 0 & 0 \\
\hline Total & 37 & 100 \\
\hline \multicolumn{3}{|c|}{ Lama Bekerja sebagai Auditor } \\
\hline$\leq 1$ tahun & 8 & $21,6 \%$ \\
\hline $1-5$ tahun & 22 & $59,5 \%$ \\
\hline 5-6 tahun & 5 & $13,5 \%$ \\
\hline$\geq 6$ tahun & 2 & $5,4 \%$ \\
\hline Total & 37 & 100 \\
\hline \multicolumn{3}{|l|}{ Jabatan } \\
\hline Senior & 6 & $16,2 \%$ \\
\hline Junior & 31 & $83,8 \%$ \\
\hline Total & 37 & 100 \\
\hline \multicolumn{3}{|c|}{ Rata-rata Jumlah Penugasan } \\
\hline $1-3$ tugas & 21 & $56,8 \%$ \\
\hline 4-7 tugas & 6 & $16,2 \%$ \\
\hline 8-10 tugas & 8 & $21,6 \%$ \\
\hline$\geq 10$ tugas & 2 & $5,4 \%$ \\
\hline Total & 37 & 100 \\
\hline
\end{tabular}

Sumber: Data primer diolah, 2016

\subsection{Uji Validitas dan Realibilitas Instrumen}

Uji validitas digunakan untuk mengukur kualitas kuesioner yang digunakan sebagai instrumen penelitian. Berdasarkan hasil pengujian validitas terhadap masing-masing butir 
pertanyaan, semua item pertanyaan dalam penelitian ini adalah valid. Butir pertanyaan valid terbukti dengan nilai $r$ hitung yang lebih besar dari $r$ tabel $(r$ tabel $=0,3246)$.

Uji reliabilitas digunakan untuk mengetahui apakah kuesioner yang dibagikan kepada responden memenuhi syarat reliable. Pengujian reliabilitas dilakukan dengan menggunakan coeficient cronbach alpha dengan batas toleransi 0,6 untuk data yang dapat dianggap reliable. Berdasarkan pengujian realibilitas diketahui bahwa seluruh variabel penelitian ini dapat dinyatakan sangat reliabel karena koefisien alpha lebih besar dari 0,6. Terlihat dalam Tabel 2 berikut ini :

Tabel 2. Hasil Uji Realibilitas

\begin{tabular}{|l|l|l|}
\hline Variabel & Cronbach Alpha & Keterangan \\
\hline Skeptisisme Profesional & 0,981 & Reliabel \\
\hline Situasi Audit & 0,903 & Reliabel \\
\hline Pengalaman & 0,938 & Reliabel \\
\hline Keahlian & 0,835 & Reliabel \\
\hline Beban Kerja & 0,939 & Reliabel \\
\hline Opini Auditor & 0,877 & Reliabel \\
\hline
\end{tabular}

Sumber : Data diolah, 2016

\subsection{Uji Asumsi Klasik}

Sebelum dilakukan regresi berganda, maka terlebih dahulu data harus terbebas dari asumsi klasik. Uji asumsi klasik dalam model ini meliputi uji normalitas, uji heteroskedastisitas dan uji multikolinearitas. Hasil pengujian normalitas menunjukkan bahwa data residual dalam model regresi berdistribusi normal. Hal ini terbukti dengan nilai asymp sig. (2-tailed) diatas 0,05 yaitu sebesar 0,881 .

Pengujian ada tidaknya heteroskedastisitas dalam model regresi dilakukan dengan menggunakan uji glejser. Hasil uji Glejser diketahui bahwa nilai signifkansi masing-masing variabel $>0,05$. Hasil tersebut dapat disimpulkan bahwa tidak terdapat gejala heteroskedastisitas dalam model regresi.

Uji asumsi klasik yang ketiga adalah uji multikolinearitas. Uji ini dapat dilakukan dengan menghitung nilai Variance Inflation factor (VIF) dan nilai toleransi dari masing-masing variabel bebas dalam model regresi. Tidak adanya masalah multikolinieritas dalam model regresi ditandai dengan nilai VIF kurang dari 10 dan nilai tolerance lebih dari 0,1. Dari hasil perhitungan diperoleh bahwa pada bagian collinierity statistic, nilai VIF pada seluruh variable independen lebih kecil dari 10 dan nilai tolerance di atas 0,1 . Oleh karena itu dapat diartikan bahwa seluruh variabel independen pada penelitian ini tidak terdapat gejala multikolinieritas. Terbebasnya data dari asumsi klasik berarti data dapat digunakan untuk analisis lebih lanjut.

\subsection{Analisis Regresi Linear Berganda}


Analisis regresi linier berganda digunakan untuk menguji kekuatan pengaruh skeptisisme profesional, pengalaman, situasi audit, keahlian dan beban kerja terhadap ketepatan pemberian opini auditor. Hasil regresi linear berganda dijelaskan dalam Tabel 3.

Tabel 3. Hasil Regresi Linear Berganda

\begin{tabular}{|l|c|c|c|c|}
\hline \multicolumn{1}{|c|}{ Variabel } & Koef. Regresi & thitung & Sig t & Keterangan \\
\hline Konstanta & -0.774 & -1.397 & 0.172 & \\
\hline Skeptisisme Profesional (SK) & 0.149 & 2.054 & 0.049 & Signifikan \\
\hline Pengalaman (PA) & 0.024 & 0.336 & 0.739 & Tidak Signifikan \\
\hline Situasi Audit (SA) & 0.202 & 2.261 & 0.031 & Signifikan \\
\hline Keahlian (KA) & 0.085 & 1.000 & 0.325 & Tidak Signifikan \\
\hline Beban Kerja (BK) & -0.105 & -1.620 & 0.115 & Tidak Signifikan \\
\hline Adj.R square & 0.551 & & & \\
\hline
\end{tabular}

Sumber : Data Primer yang diolah, 2016

Berdasarkan Tabel 3. di atas maka model persamaan regresi yang diperoleh adalah sebagai berikut:

$$
\mathrm{OP}=-\mathbf{0 , 7 7 4}+0,149 \mathrm{SK}+0,024 \mathrm{PA}+0,202 \mathrm{SA}+0,085 \mathrm{KA}-0,105 \mathrm{BK}
$$

Dari persamaan regresi yang dihasilkan dapat disimpulkan bahwa ada empat variabel yaitu skeptisisme profesional, situasi audit, pengalaman dan keahlian yang memiliki hubungan yang positif serta beban kerja mempunyai hubungan negatif dengan ketepatan pemberian opini auditor oleh akuntan publik.

Hasil analisis koefisien determinasi, dihasilkan nilai koefisien determinasi (Adjusted R2) sebesar 0,551. Hasil tersebut dapat disimpulkan bahwa besarnya variasi variabel independen dalam mempengaruhi model persamaan regresi adalah sebesar 55,1\% dan sisanya sebesar 44,9\% dipengaruhi oleh faktor-faktor lain yang tidak dimasukkan dalam model regresi.

\subsection{Pengujian Hipotesis dan Pembahasan}

1) Pengaruh Skeptisisme profesional terhadap ketepatan pemberian opini auditor

Pengujian terhadap hipotesis ini dilakukan melalui pengujian signifikansi thitung dari variabel skeptisisme profesional. Hasil perhitungan pada regresi berganda diperoleh nilai $t_{\text {hitung }}$ sebesar 2,054 dengan signifikansi sebesar 0,049 sehingga dapat diketahui sig $t_{\text {hitung }}<0,05$. Beradasarkan hasil pengujian hipotesis diatas maka dapat disimpulkan bahwa variabel skeptisisme profesional secara parsial memiliki pengaruh positif signifikan terhadap ketepatan 
pemberian opini auditor, sehingga hipotesis pertama penelitian ini diterima. Hasil penelitian ini mendukung penelitian yang dilakukan Suraida (2005) yang menemukan bahwa terdapat pengaruh yang besar antara skeptisisme profesional auditor terhadap ketepatan pemberian oponi auditor oleh akuntan publik. Artinya semakin tinggi tingkat skeptis seorang auditor maka semakin tepat pula opini auditor yang akan diberikannya. Gusti dan Ali (2008) pun demikian menemukan bahwa terdapat hubungan yang signifikan antara skeptisisme profesional dengan ketepatan pemberian opini auditor oleh akuntan publik. Auditor dengan tingkat skeptisisme yang tinggi tentu akan lebih teliti dalam melakukan pekerjaan audit dan tidak mudah terpengaruh oleh informasi yang bias, sehingga pada akhirnya akan memberikan opini yang tepat atas laporan keuangan yang di audit.

Auditor bertanggungjawab untuk memberikan opini terhadap hasil audit yang telah dilakukan dengan baik dan benar. Untuk mencapai hal tersebut, pengauditan harus direncanakan dan dilakukan dengan sikap skeptisme professional dalam segala hal yang terkait dengan kegiatan pengauditan. Hal ini sesuai dengan teori yang dikemukakan oleh Arens (2007) yang menyatakan pemahaman menyeluruh atas entitas dan lingkungannya serta pengetahuan tentang operasi entitas sangat penting untuk melaksanakan audit yang memadai. Menurut Arens (2007) auditor harus bertanggung jawab secara profesional dalam pelaksanaan tugasnya untuk bersikap skeptis. Sebagai ilustrasi, perhatian mendalam termasuk pertimbangan akan kelengkapan kertas kerja, kecukupan bukti audit, serta ketepatan laporan audit. Karena bukti dikumpulkan dan dievaluasi selama pemeriksaan, skeptisme profesional harus digunakan selama pemeriksaan Sehingga auditor dapat memberikan opini yang tepat dan menghasilkan audit yang berkualitas.

Hasil inipun sesuai dengan teori auditing yang dikemukakan oleh Mautz dan Sharaf (1961) yang menjelaskan bahwa seorang auditor harus memiliki sifat kehati-hatian dalam proses pemeriksaannya dan selalu mengindahkan norma-norma profesi dan norma moral yang berlaku. Sama halnya dengan skeptisisme profesional auditor yang memiliki arti bahwa seorang auditor harus memiliki sifat curiga terhadap klien, agar dapat mengajukan pertanyaan untuk diperoleh bukti secara kompeten, sehingga bukti tersebut nantinya akan memperkuat dasar pengambilan kesimpulan yang tertuang dalam pendapat auditor. Seorang auditor yang telah menggunakan sikap skeptisisme dalam proses pemeriksaan akan cenderung lebih tepat pada saat memberikan sebuah opini sesuai dengan kondisi perusahaan klien karena akan lebih bersifat hati-hati dalam mengevaluasi temuan audit.

2) Pengaruh Pengalaman terhadap ketepatan pemberian opini auditor

Hasil perhitungan pada regresi berganda diperoleh nilai $t_{\text {hitung }}$ sebesar 0,336 dengan signifikansi sebesar 0,739 sehingga dapat diketahui sig $t_{\text {hitung }}>0,05$. Berdasarkan hasil pengujian hipotesis diatas maka dapat disimpulkan bahwa pengalaman tidak mempunyai pengaruh yang signifikan terhadap ketepatan pemberian opini auditor, sehingga hipotesis kedua penelitian ini ditolak. Alasan penolakan hipotesis ini diduga bahwa data responden berdasarkan pengalaman 
audit dalam penelitian ini hasilnya sangat bervariasi dan rata-rata yang mengisi kuesioner adalah auditor junior yang masih sedikit pengalamannya dan baru bekerja sebagai auditor antara 1-5 tahun dengan jumlah penugasan 1-3 penugasan. Pengalaman yang diukur berdasarkan lamanya seorang auditor bekerja pada suatu kantor akuntan publik tidak menjamin bahwa opini yang diberikannya selalu tepat. Hal ini tergantung pula pada seringnya auditor menangani kasus dengan permasalahan audit yang berbeda-beda sehingga kemampuannya dalam audit menjadi lebih luas. Hal ini didukung oleh penelitian Puspa (2006) dalam Kushasyandita (2012) yang menyatakan bahwa pertanyaan pada kuesioner dengan ilustrasi yang berbeda melatarbelakangi penilaian dan persepsi masing-masing responden yang bervariasi walaupun pengalaman yang hampir sama ternyata memiliki pertimbangan yang berbeda-beda dan sangat bervariasi. Hal yang sama dinyatakan oleh Gusti dan Ali (2008) bahwa pengalaman tidak berpengaruh signifikan terhadap ketepatan pemberian opini auditor oleh akuntan publik. Begitupun dengan Surfeliya (2014) yang menolak bahwa pengalaman berpengaruh terhadap ketepatan pemberian opini auditor BPK.

3) Pengaruh Situasi audit terhadap ketepatan pemberian opini auditor

Hasil perhitungan pada regresi berganda diperoleh nilai $t_{\text {hitung }}$ sebesar 2,261 dengan signifikansi sebesar 0,031 sehingga dapat diketahui sig $t_{\text {hitung }}<0,05$. Berdasarkan hasil pengujian hipotesis diatas maka dapat disimpulkan bahwa situasi audit secara parsial memiliki pengaruh positif signifikan terhadap ketepatan pemberian opini auditor, sehingga hipotesis ketiga penelitian ini diterima. Hasil penelitian ini mendukung penelitian milik Gusti dan Ali (2008) yang juga menemukan bahwa situasi audit berpengaruh terhadap ketepatan pemberian opini auditor oleh akuntan publik. Berbagai macam situasi yang dihadapi auditor terutama situasi yang mengandung resiko tinggi akan meningkatkan tingkat ketelitian seorang auditor dalam pekerjaan audit supaya audit yang dilakukan efektif dan berkualitas yang ditandai dengan pemberian opini yang tepat.

Situasi audit akan memunculkan kepekaan pada diri auditor dalam mengahadapi situasi audit yang bermacam-macam dan dapat dijadikan pertimbangan dalam memutuskan opini audit yang diberikan. Adanya kontrol perilaku yang auditor rasakan bergantung dari situasi dan variasi persepsi tersebut yang dapat menghasilkan berbagai pengendalian perilaku yang bergantung dari situasi yang ada. Sehingga dalam hal ini, auditor akan lebih mempertimbangkan mengenai opini apa yang nantinya akan diberikan sesuai dengan situasi yang terjadi dalam pemeriksaan.

4) Pengaruh Keahlian terhadap ketepatan pemberian opini auditor

Hasil perhitungan pada regresi berganda diperoleh nilai $t_{\text {hitung }}$ sebesar 1,000 dengan signifikansi sebesar 0,325 sehingga dapat diketahui sig $t_{\text {hitung }}>0,05$. Beradasarkan hasil pengujian hipotesis diatas maka dapat disimpulkan bahwa keahlian tidak mempunyai pengaruh yang signifikan terhadap ketepatan pemberian opini auditor, sehingga hipotesis keempat penelitian ini ditolak. Menurut Simamora (2002) dalam Kushasyandita (2012) keahlian ditentukan oleh pendidikan kesarjanaan formal, pelatihan dan partisipasi dalam program edukasi yang 
berkelanjutan selama karir profesi, semakin tinggi tingkat pendidikan kesarjanaan formalnya maka semakin tepat dalam melaksanakan prosedur audit sehingga opini yang diberikan tepat. Penolakan hipotesis keempat pada penelitian ini diduga karena sebagian besar responden yang mengisi kuesioner berpendidikan S1, bahkan ditemukan adanya auditor berpendidikan D3, sehingga dalam pemberian opininya belum semahir auditor yang berpendidikan S2 atau S3. Hal ini didukung oleh penelitian Gusti dan Ali (2008) serta Kushasyandita (2012) yang menyatakan bahwa keahlian tidak berpengaruh signifikan terhadap pemberian opini auditor oleh akuntan publik.Keahlian auditordalam penelitian ini tidak tergolong tinggi, terlihat dari jawaban responden mengenai pendidikan formal dan tingkat sertifikasi yang dimiliki auditor tersebut rendah. Menurut Kushasyandita (2012) auditor yang berpendidikan lebih tinggi akan mempunyai pandangan yang lebih luas mengenai berbagai hal dan lebih mudah dalam mengikuti perkembangan yang semakin kompleks. Tetapi justru dalam penelitian ini jumlah responden yang berpengetahuan tinggi dan mengenyam pendidikan tinggi sangat minim sehingga hasilnya tidak signifikan.

5) Pengaruh beban kerja terhadap ketepatan pemberian opini auditor

Hasil perhitungan pada regresi berganda diperoleh nilai $t_{\text {hitung }}$ sebesar -1,620 dengan signifikansi sebesar 0,115 sehingga dapat diketahui sig $t_{\text {hitung }}>0,05$. Berdasarkan hasil pengujian hipotesis diatas maka dapat disimpulkan bahwa beban kerja tidak mempunyai pengaruh yang signifikan terhadap ketepatan pemberian opini auditor, sehingga hipotesis kelima penelitian ini ditolak. Disaat seorang auditor mendapat beban kerja yang lebih besar yang bisa saja dipengaruhi oleh permintaan klien atau desakan waktu, auditor akan cenderung tidak fokus terhadap pekerjaan auditnya, sehingga kemampuannya untuk lebih teliti dalam menemukan kecurangan akan melemah, selain itu bisa juga auditor akan mengurangi beberapa prosedur audit yang mengakibatkan opini yang diberikan kurang tepat. Alasan penolakan hipotesis kelima ini adalah karena beban kerja auditor yang menjadi responden dalam penelitian ini cukup rendah. Hal ini mungkin disebabkan karena auditor junior masih diberikan tugas atau pekerjaan yang ringan dan tidak seberat auditor senior, manajer ataupun partner. Hasil penelitian ini tidak mendukung penelitian milik Nasution (2012) yang menyatakan bahwa beban kerja mempengaruhi kualitas skeptisisme auditor yang akan berdampak pada ketidaktepatan pemberian opini, serta penelitian milik Fitriany (2011) yang menemukan bahwa meningkatnya beban kerja akan menurunkan kemampuan auditor dalam menemukan indikasi kecurangan dan menurunkan kinerja auditor dalam melalukan pengauditan.

\section{KESIMPULAN}

Berdasarkan hasil penelitian yang telah dilakukan, maka dapat diambil kesimpulan sebagai berikut : 
1) Skeptisisme Profesional berpengaruh positif signifikan terhadap ketepatan pemberian opini auditor pada KAP di Daerah Istimewa Yogyakarta. Hal ini berarti semakin meningkat sikap skeptis seorang auditor maka opini yang diberikan akan semakin tepat.

2) Pengalaman tidak berpengaruh signifikan positif terhadap ketepatan pemberian opini auditor pada KAP di Daerah Istimewa Yogyakarta. Hal ini berarti tinggi rendahnya pengalaman tidak mempengaruhi ketepatan pemberian opini oleh auditor. Hal ini mungkin dipengaruhi oleh jumlah responden yang digunakan dalam penelitian ini hanya sedikit, disamping responden yang mengisi kuesioner adalah auditor junior yang memiliki pengalaman audit belum banyak sehingga tidak representatif.

3) Situasi Audit berpengaruh signifikan positif terhadap ketepatan pemberian opini auditor pada KAP di Daerah Istimewa Yogyakarta. Hal ini berarti auditor akan semakin peka dalam menghadapi situasi audit yang bermacam-macam dan dapat dijadikan pertimbangan dalam memutuskan opini audit yang diberikan.

4) Keahlian tidak berpengaruh signifikan positif terhadap ketepatan pemberian opini auditor pada KAP di Daerah Istimewa Yogyakarta. Hal ini berarti tinggi rendahnya keahlian tidak mempengaruhi ketepatan pemberian opini oleh auditor. Hal ini mungkin dipengaruhi oleh jumlah responden yang digunakan dalam penelitian ini hanya sedikit, disamping responden yang mengisi kuesioner adalah auditor dengan latar belakang pendidikan S1 yang pengetahuan, kemampuan dan keahlian dalam mengauditnya belum terlalu banyak.

5) Beban kerja tidak berpengaruh signifikan negatif terhadap ketepatan pemberian opini auditor pada KAP di Daerah Istimewa Yogyakarta. Hal ini menunjukkan bahwa sebesar apapun beban kerja yang dipikul auditor karena berada pada busy season terutama pada bulan Desember sampai Maret tidak akan menurunkan kinerja auditor dan ketelitian auditor dalam mengevaluasi bukti yang akan berakibat pada ketidaktepatan pemberian opini.

\subsection{Implikasi}

1) Melalui penelitian ini diketahui bahwa faktor skeptisisme profesional, dan situasi audit berpengaruh terhadap ketepatan pemberian opini oleh auditor. Oleh karena itu agar dapat menjadi auditor yang berkualitas dengan memberikan opini yang tepat, seorang auditor harus memperhatikan dan menjadikan faktor-faktor di atas sebagai patokan dan menerapkannya dalam melaksanakan audit.

2) Dalam meningkatkan kualitas audit yang baik maka KAP harus memperhatikan faktor-faktor yang dapat mempengaruhi ketepatan pemberian opini auditor. KAP harus mampu meningkatkan skeptisisme auditor melalui penyusunan program audit yang tepat dan meningkatkan supervisi terhadap asisten atau auditor yunior.

\subsection{Keterbatasan dan Saran}


Hasil pengujian ini terdapat tiga hipotesa yang tidak terdukung oleh data. Hal ini disebabkan karena terdapat beberapa keterbatasan dalam penelitian. Keterbatasan tersebut diantaranya adalah :

1) Pengumpulan data di dalam penelitian hanya menggunakan kuesioner sehingga data yang diperoleh belum dapat merepresentasikan secara keseluruhan mengenai skeptisisme profesional, pengalaman, situasi audit, keahlian dan beban kerja terhadap ketepatan pemberian opini auditor. Diharapkan penelitian selanjutnya bisa dilakukan dengan wawancara kepada auditor sehingga jawaban yang diperoleh benar-benar sesuai dengan kondisi auditor.

2) Jumlah responden yang digunakan hanya sebanyak 37 responden yang terbatas pada KAP di Yogyakarta. Diharapkan penelitian selanjutnya menambah jumlah responden dalam skala yang lebih besar. 


\section{DAFTAR PUSTAKA}

Agoes, S. (2012). Auditing Pemerikasaan Akuntansi Oleh Akuntan Publik. (Edisi Ketiga). Jakarta: Penerbit Fakultas Ekonomi Universitas Trisakti

Adrian, A. (2009). Pengaruh Skeptisisme Profesional, Etika, Pengalaman, dan Keahlian Audit terhadap Ketepatan Pemberian Opini oleh Auditor (Studi empiris pada BPK RI Perwakilan Provinsi Riau). Skripsi S1 Universitas Negeri Padang.

Arens, Alvin A., Elder. R.J., Mark, S., Beasly. Auditing dan Jasa Assurance.(2006). Jakarta: Erlangga.

Asih (2006). Pengaruh Pengalaman Terhadap Peningkatan Kealian Auditor dalam Bidang Auditing. Skripsi S1 Universitas Islam Indonesia.

Butt, J.I. (1998). Frecuency Judgement I an Auditing- Related Lask. Journal of Accounting Research. Vol 26 (1)

Christiawan, Y.J. (2002). Kompetensi dan Independensi Akuntan Publik: Refleksi Hasil Penelitian Empiris. Jurnal Akuntansi dan Keuangan Unika Petra.

Dhania, D.R. (2010). Pengaruh Stress Kerja, Beban kerja Terhadap Kepuasan Kerja (Studi Pada Medical Representatif Di Kota Kudus). Skripsi S1 Universitas Muria Kudus.

Fitriany. (2011). Analisis Komprehensif Pengaruh Kompetensi dan Independensi Akuntan Publik Terhadap Kualitas Audit. Disertasi S3 Universitas Indonesia.

Fitriany dan Liswan S.W. (2011) pengaruh Workload dan spesialisasi Auditor Terhadap Kualitas Audit Dengan Komite Audit Sebagai Variabel Pemoderasi. Jurnal Akuntansi dan Keuangan Indonesia. Vol 8.

Ghozali, I. (2005). Aplikasi Analisis Multivariant dengan Program SPSS. Semarang: Bp Undip.

Gusti, M., dan Ali, S. (2008). Hubungan Skeptisisme Profesional Auditor dan Situasi Audit, Etika, pengalaman Serta Keahlian Audit dengan Ketepatan pemberian Opini oleh Akuntan Publik. Simposium Nasional Akuntansi XI Pontianak. 23-24 Juli 2008.

Hergiawan, A. (2013). Faktor yang Mempengaruhi Skeptisisme Auditor Eksternal untuk Meningkatkan kemampuan Mendeteksi Kecurangan. Skripsi S1 Universitas Islam Indonesia.

Institut Akuntan Publik Indonesia. (2012). Standar perikatan audit ("SPA") 700 Perumusan Suatu Opini dan Pelaporan Atas Laporan Keuangan. Exposure Draft. Jakarta.

Kushasyandita, S. dan Indira, J. (2012). Pengaruh Pengalaman, Keahlian, Situasi Audit, etika dan gender terhadap Ketepatan Pemberian Opini Auditor melalui Skeptisisme profesional Auditor (Studi Kasus pada KAP Big Four di Jakarta). Jurnal Sistem Informasi, Etika dan Auditing.

Libby, R., Frederick, D.M. (1990). Experience And The Ability To Explain Audit Findings. Journal of Accounting Research, Vol.28, hal. 348-67.

Lopez, Dennis, M., and Gary, F., Peters. (2011). The Effect of Workload Compression on Audit Quality. Auditing, Vol.31, hal. 139-165.

Mautz, Robert Kuhn and Sharaf, Hussein A. (1961). The Philosophy of Auditing, American Accounting Association.

Murtiasri, E., dan Imam, G. (2006). Anteseden dan Konsekuensi Burnout pada Auditor: Pengembangan Terhadap Role Stress Model. Simposium Nasional Akuntansi IX, Padang. 2326 Agustus 2006.

Nasution, H. (2012). Pengaruh Beban Kerja, Pengalaman Audit dan Tipe Kepribadian terhadap Skeptisisme Profesional dan Kemampuan Mendeteksi Kecurangan. Simposium Nasional Akuntansi XV, Banjarmasin. 20-23 September 2012.

Pitaloka, D. (2010). Pengaruh Kondisi Kerja dan Beban Kerja terhadap Stres Kerja pada Perawat di Ruang Rawat Inap RSU Kaban Jahe Kab. Karo. Tesis S2 Universitas Sumatra Utara.

Puspa, A., Enggar Diah. (2006). "Pengaruh Persuasi atas Preferensi Klien dan Pengalaman Audit terhadap Pertimbangan Auditor dalam Mengevaluasi Bukti Audit." Tesis Tidak Dipublikasikan. Program Pascasarjana, Universitas Padjadjaran.

Shirom, A., Nirel, and Vinokur, A.D. (2006). Overload, Autonomy, and Burnout as Predictors of Physicians Quality of Care. Jounal of Occupational Health Psychology, No.11 (4), pp 328342.

Standar Profesional Akuntan Publik. (2011). IAPI. Jakarta:Salemba Empat 
Sugiyono. (2004). Metode penelitian Bisnis. Bandung: CV Alfabeta.

Sukendra, P., Gede A.Y., dan Anantawikrama T.A. (2015). Pengaruh Skeptisisme Profesional, Pengalaman Auditor, dan Keahlian Audit terhadap Ketepatan Pemberian Opini oleh Auditor (Studi Empiris pada Inspektorat Kabupaten Buleleng, Kabupaten Bangli dan Kabupaten Karangasem). e-journal S1 Ak Universitas Pendidikan Ganesha. Vol.3 (1).

Suraida, I. (2005). Pengaruh Etika, Kompetensi, Pengalaman Audit Dan Risiko Audit Terhadap Skeptisisme Profesional Auditor dan Ketepatan Pemberian Opini Akuntan Publik. Sosiohumaniora. Vol.7 ( 3), pp 186-202.

Surfeliya, F., Andreas, dan Yusralaini. (2014). Professional Influence Skeptisisme, Competition, Audit Situation, Audit Ethics, Experience and Expertise Make an Audit of to Accuracy of Audit Opinion by Auditor BPK. Jom Fekon. Vol.1 (2)

Tirta, R., dan Sholihin, M. (2004). The Effect of Experience and Task Specific Knowledge on Auditor's Perfomance in Assessing A fraud Case. JAAI, Vol. 8, pp 1-21.

Winantyadi, Ndaru dan Waluyo, Indarto. (2014). Pengaruh Pengalaman, Keahlian, Situasi Audit, dan Etika Terhadap Skeptisisme Profesional Auditor. Jurnal Nominal. Indonesia: Yogyakarta. Volume III Nomor 1.

Zein, Z.A., Yuneita, A., dan Christina. (2011). Skeptisisme Profesioanl Auditor Pada kantor Akuntan Publik Di Sumatera. Jurnal Pekbis, Vol.3 (2), hal 490-49. 